\title{
Proximate Analysis, Protein and Starch Digestibility, Specific Volume, and Sensory Evaluation of (Gluten-Free) Tin Bread
}

\author{
Mohammed Abdel Rahman Hussain Ahmed ${ }^{*}$, Abdelmoneim Ibrahim Mustafa², \\ Hayat Abdel Rahman Hussan ${ }^{3}$, Ahmed Elawad Elfaki ${ }^{1}$ \\ ${ }^{1}$ Department of Food Science and Technology, Faculty of Agricultural Studies, University of Sudan, \\ Khartoum, Sudan \\ ${ }^{2}$ Department of Food Science and Technology, Faculty of Agriculture, University of Khartoum, Khartoum, Sudan \\ ${ }^{3}$ Department of Cereal Science and Technology, Food Research Centre, Khartoum, Sudan \\ Email: *mohmammedfd555@hotmail.com
}

Received 30 April 2016; accepted 11 June 2016; published 15 June 2016

Copyright (C) 2016 by authors and OALib.

This work is licensed under the Creative Commons Attribution International License (CC BY).

http://creativecommons.org/licenses/by/4.0/

(c) (i) Open Access

\begin{abstract}
The increasing demand for gluten free product had forwarded the design of numerous gluten free bakery product which intended to mimic the quality characteristics of wheat bakery products. The objective of this study was to formulate bakery products such as tin breads from decorticated sorghum and maize flour supplemented with improvers (chickpea $0 \%, 10 \%, 20 \%$ and $30 \%$ and others), and to determine its quality attribute like proximate analysis, digestibility of protein and starch and to assess consumer acceptability. Moisture, ash, fat, protein, fiber, carbohydrates, and energy of tin breads (gluten-free) showed great variation ranging from $9.55 \%$ to $10.47 \%, 1.40 \%$ to $2.45 \%, 1.67 \%$ to $3.15 \%, 10.08 \%$ to $16.91 \%, 0.85 \%$ to $2.10 \%, 66.34 \%$ to $74.51 \%$ and $355.26 \%$ to $359.96 \% \mathrm{kcal} / 100 \mathrm{gm}$, respectively. Likewise, in vitro protein and starch digestibility increased significantly $(P \leq 0.05)$ from 43.35 to $58.54 \%$ and from $62.55 \%$ to $67.54 \%$, respectively. Loaf specific volume ranged from 2.11 to $2.79 \mathrm{cc} / \mathrm{gm}$. General acceptability of breads produced showed that no significant differences were noticed that means all the samples treated studied were accepted. Finally, gluten free breads (tin breads) supplemented with chickpea flour could provide a good source of protein for the consumers and especially celiac disease patients.
\end{abstract}

\section{Keywords}

Proximate Analysis, Protein and Starch Digestibility, Specific Volume and Sensory Evaluation of Tin Breads (Gluten-Free)

Subject Areas: Food Science \& Technology

\footnotetext{
${ }^{*}$ Corresponding author.
}

How to cite this paper: Ahmed, M.A.R.H., Mustafa, A.I., Hussan, H.A.R. and Elfaki, A.E. (2016) Proximate Analysis, Protein and Starch Digestibility, Specific Volume, and Sensory Evaluation of (Gluten-Free) Tin Bread. Open Access Library Journal, 3: e2698. http://dx.doi.org/10.4236/oalib.1102698 


\section{Introduction}

Schober, et al., 2005 [1] confirmed that it was possible to produce good sorghum bread with sorghum flour and up to 30 percent corn starch. Furthermore, the kind of sorghum flour used played an important role in the end product. Schober, et al., 2005 [1] showed that clear differences were found between various sorghum hybrids in their potential to produce gluten-free leavened bread. In their results, they explained that crumb structure differed most characteristically, whereas, volume and height did not show significant differences among the samples evaluated. Frederick, 2009 [2] also established that sorghum flour composition and particle size had an effect on the quality of gluten-free bread. This study also validated the impact of starch damage on bread performance. Additionally, Marston, 2009 [3] revealed that treating sorghum flour with ozone and heat affected the quality of gluten-free bread. When sorghum flour was ozonated, the bread produced was characterized by an extremely poor structure. However, heat treatment showed positive effects on the quality of gluten-free bread. When sorghum flour was heated to $125^{\circ} \mathrm{C}$ prior to use, bread volume, was improved probably due to the oxidation of sulfhydryl units. This volume improvement also led to an amelioration of both the crumb structure and the texture.

Schober, 2009 [4] also explained that the typical bread making procedure for sorghum bread was simply mixing, followed by a final proof in bake pans and baking. Studies on which he based his review all agreed that higher water levels than for regular breads were required for good results; however, excessively high water levels reduced bread quality in term of volume and structure. Coeliac disease was a syndrome characterized by damage to the mucosa of the small intestine caused by ingestion of certain wheat proteins and related proteins in rye and barley (Fasano, and Catassi, 2001) [5]. Thegliadins (Kagnoff, et al., (1982) [6] and glutenins (Van de Wal, et al., 1999) [7] of wheat gluten had been shown to contain protein sequences that were not tolerated by coeliacs. Modern screening studies showed that coeliac disease was much more prevalent than previously thought. The average worldwide prevalence had been estimated as high as 1: 266 (Fasano, and Catassi, 2001) [5]. Estimates placed the number of persons with coeliac disease in the USA at roughly 3 million. The cornerstone treatment for coeliac disease was the total lifelong avoidance of gluten ingestion.

The objectives of this research focus on: to formulate bakery products such as bread from sorghum and maize flours supplemented with improvers; to determine the in vitro protein and starch digestibility of the final products; to determine the nutritional quality of final product; to assess consumer acceptability of the bread produced.

\section{Materials and Methods}

\subsection{Materials}

Samples preparation: Sorghum, maize and chickpea samples were cleaned from dust, husk, and other impurities, then sorghum and maize were decorticated to $90 \%$ extraction, then all samples milled using laboratory Miller Type 120, No. 69444 Helsinki-Stockholm-Sweden and through mesh (250 micrometer) into fine powder.

\subsection{Methods}

\subsubsection{Chemical Composition}

Moisture, ash, crude protein and fat contents were determined for decorticated sorghum, maize-chickpeaflour supplemented products according to AOAC, (2000) [8] method. Fiber content was carried out on the samples according to AACC, (2000) [9] methods. The carbohydrates were calculated by difference. The sum of moisture, fat, protein and ash contents were subtracted from 100 as it was described by West, et al., (1988) [10]. The energy values of the biscuits were calculated for protein, fat and carbohydrates based on Atwater factors, (1902) [11]:

Fat factor $=9.0(\mathrm{kcal} / \mathrm{g})$.

Protein factor $=4.0(\mathrm{kcal} / \mathrm{g})$.

$\mathrm{CHO}$ factor $=4.0(\mathrm{kcal} / \mathrm{g})$.

$1 \mathrm{kcal}=4.184(\mathrm{kj})$.

\subsubsection{In Vitro Protein Digestibility}

In vitro protein digestibility of sample was carried out using enzymatic method of Mouliswar, et al., (1993) [12]. Samples containing $100 \mathrm{mg}$ protein were treated with $12.5 \mathrm{mg}$ of pepsin in $50 \mathrm{ml}$ of $0.1 \mathrm{~N} \mathrm{HCl}$ at $37^{\circ} \mathrm{C}$ for 3 
hours. After neutralization with $0.5 \mathrm{~N} \mathrm{NaOH}, 6 \mathrm{mg}$ of pancreatin dissolved in $25 \mathrm{ml}$ of phosphate buffer (pH 8.0) was added and digestion continued for 24 hour at $37^{\circ} \mathrm{C}$. The volume was made to $100 \mathrm{ml}$ and $50 \mathrm{ml}$ aliquot was treated with 10 per cent TCA, left overnight to precipitate the proteins. The suspensions were centrifuged at $4000 \mathrm{rpm}$ for 20 minutes at room temperature. The undigested material was subjected to protein assay by micro Kjeldahl method. Protein digestibility was calculated by difference.

\subsubsection{In Vitro Starch Digestibility}

In vitro starch digestibility was carried out using the method, described by Mouliswar, et al., (1993) [12]. The slurry of sample (2\%) was cooked on a boiling water bath for 15 minutes. To a slurry sample of $50 \mathrm{ml}, 30 \mathrm{ml}$ of $0.2 \mathrm{M}$ glycine-HCl buffer (pH 2.0) containing $10 \mathrm{mg}$ of pepsin was added. It was incubated at $37^{\circ} \mathrm{C}$ for 2 hours and neutralized with $0.2 \mathrm{~N} \mathrm{NaOH}$ and the volume was made to $100 \mathrm{ml}$. To an aliquot of $10 \mathrm{ml}$ of this sample 5 $\mathrm{ml}$ of $0.5 \mathrm{M}$ phosphate buffer containing $15 \mathrm{mg}$ of pancreatin and $15 \mathrm{mg}$ amyloglucosidase was added and incubated for 2 hours at $37^{\circ} \mathrm{C}$. The reaction was stopped at desired intervals ( 3 hours) by heating the samples for 5 minutes in boiling water bath. Aliquots of $0.5 \mathrm{ml}$ of these samples were mixed with $2 \mathrm{ml}$ of dinitrosalicylicacid reagent for determining reducing sugars. Glucose was used as a standard, while starch equivalent was calculated using the conversion factor of 0.9. (A A C C, 1969) [13].

\subsubsection{Loaf Bread}

The procedure described byBadi, et al., (1978) [14] was modified for this type of bread. Decorticated sorghum and maize flour bread were incorporated with chickpea flour at 10, 20, and 30\% \% levels. Dry ingredients (flour $250 \mathrm{~g}$, dry yeast $2.5 \mathrm{~g}$, salt $1.5 \mathrm{~g}$, sugar $3 \mathrm{~g}$ and $2.5 \%$ xanthan gum) were mixed for 1 min. using Mono-Universal laboratory dough mixer. Water was added (based on the optimum absorption) and mixed for 3 min at medium speed. After mixing the dough was allowed to rest for $10 \mathrm{~min}$. at room temperature $\left(38^{\circ} \mathrm{C} \pm 2^{\circ} \mathrm{C}\right)$, scaled to three portions of $150 \mathrm{~g}$ each, and put in pans and transferred into the fermentation cabinet for $45 \mathrm{~min}$. The fermented dough's were then baked in Simon Rotary baking oven at $250^{\circ} \mathrm{C}$ for $15 \mathrm{~min}$.

\subsubsection{Sensory Evaluation of Loaf Bread}

The loaves were sliced with an electric knife and prepared for sensory evaluation same day. The sensory evaluation of bread samples (colour, odour, crumb texture, crumb grains, and general acceptability) was carried out by 10 trained panelists. The surrounding conditions were kept the same all through the panel test.

\subsubsection{Statistical Analysis}

The analysis of variance was performed to examine the significant effect in all parameters measured. Duncan Multiple Range Test was used to separate means.

\section{Results and Discussion}

\subsection{Proximate Composition of (Gluten-Free) Tin Bread}

Proximate analysis is important for evaluating the nutritional content of the developed food products. The different chemical compositions of the tin breads made from decorticated sorghum and maize incorporated substantially with different ratio from chickpea flour (10\%, 20\%, and 30\%) has appositive effects on the nutritional quality of the final product. The contents of protein, fiber, moisture, fat, ash, carbohydrates and energy prepared are shown in Table 1. Moisture content values of the bread produced ranged between $9.55 \%$ to $10.47 \%$. Highest value noted in $S_{2}$, whereas, the lowest value observed in $\mathrm{M}_{2}$. High moisture content helps the increases of the microbial activity which may deteriorate the product during bad storage. From the current result moisture content decreased significantly $(P \leq 0.05)$ with increasing the level of chickpea flour in both sorghum and maize bread. Ash content is composed of non combustible, inorganic materials that are concentrated in the bran layer. Ash content can attributed to the mineral content in the samples. Ash content of the non-wheat bread (Tin bread) made from decorticated sorghum and maize mixed with chickpea flour with different ratio (10\%, 20\%, and 30\%) ranged from $1.40 \%$ to $2.45 \%$ for maize and sorghum bread, respectively.

Table 1 showed crude fat content of tin bread ranged from $1.67 \%$ to $3.15 \%$, for $\mathrm{M}$ and $\mathrm{S}_{3}$, respectively. Fat content increased significantly $(P \leq 0.05)$ with increasing the level of chickpea flour in the formulations of all bread samples examined. Besides providing the essential nutrition, protein can also be related to the finished 
Table 1. Proximate composition of (gluten-free) tin bread.

\begin{tabular}{cccccccc}
\hline Samples & $\begin{array}{c}\text { Moisture } \\
\text { content (\%) }\end{array}$ & $\begin{array}{c}\text { Ash content } \\
(\%)\end{array}$ & $\begin{array}{c}\text { Fat content } \\
(\%)\end{array}$ & Crude protein (\%) & $\begin{array}{c}\text { Crude fibre } \\
(\%)\end{array}$ & Carbohydrate (\%) & $\begin{array}{c}\text { Energy } \\
(\mathrm{kcal} / 100 \mathrm{gm})\end{array}$ \\
\hline $\mathrm{S}$ & $10.23^{\mathrm{b}} \pm 0.04$ & $2.45^{\mathrm{a}} \pm 0.09$ & $1.88^{\mathrm{e}} \pm 0.08$ & $10.08^{\mathrm{h}} \pm 0.11$ & $0.85^{\mathrm{e}} \pm 0.03$ & $74.50^{\mathrm{a}} \pm 0.01$ & $355.26^{\mathrm{a}} \pm 0.70$ \\
$\mathrm{~S}_{1}$ & $10.47^{\mathrm{a}} \pm 0.05$ & $2.35^{\mathrm{ab}} \pm 0.07$ & $2.30^{\mathrm{d}} \pm 0.13$ & $12.44^{\mathrm{f}} \pm 0.06$ & $1.20^{\mathrm{d}} \pm 0.10$ & $71.24^{\mathrm{b}} \pm 0.18$ & $355.41^{\mathrm{a}} \pm 0.47$ \\
$\mathrm{~S}_{2}$ & $10.10^{\mathrm{c}} \pm 0.00$ & $2.32^{\mathrm{b}} \pm 0.07$ & $2.75^{\mathrm{bc}} \pm 0.12$ & $14.03^{\mathrm{d}} \pm 0.13$ & $1.77^{\mathrm{b}} \pm 0.01$ & $69.03^{\mathrm{c}} \pm 0.20$ & $356.99^{\mathrm{a}} \pm 0.86$ \\
$\mathrm{~S}_{3}$ & $9.93^{\mathrm{d}} \pm 0.01$ & $2.00^{\mathrm{c}} \pm 0.07$ & $3.15^{\mathrm{a}} \pm 0.16$ & $15.66^{\mathrm{b}} \pm 0.26$ & $2.09^{\mathrm{a}} \pm 0.08$ & $67.18^{\mathrm{d}} \pm 0.21$ & $359.65^{\mathrm{a}} \pm 1.24$ \\
$\mathrm{M}$ & $9.97^{\mathrm{d}} \pm 0.02$ & $1.40^{\mathrm{e}} \pm 0.02$ & $1.67^{\mathrm{f}} \pm 0.12$ & $11.15^{\mathrm{g}} \pm 0.06$ & $1.30^{\mathrm{cd}} \pm 0.12$ & $74.51^{\mathrm{a}} \pm 0.24$ & $357.70^{\mathrm{a}} \pm 0.48$ \\
$\mathrm{M}_{1}$ & $9.77^{\mathrm{e}} \pm 0.05$ & $1.85^{\mathrm{d}} \pm 0.01$ & $2.23^{\mathrm{d}} \pm 0.07$ & $13.24^{\mathrm{e}} \pm 0.08$ & $1.38^{\mathrm{c}} \pm 0.10$ & $71.52^{\mathrm{b}} \pm 0.06$ & $359.14^{\mathrm{a}} \pm 0.74$ \\
$\mathrm{M}_{2}$ & $9.55^{\mathrm{f}} \pm 0.03$ & $2.01^{\mathrm{c}} \pm 0.04$ & $2.65^{\mathrm{c}} \pm 0.15$ & $15.00^{\mathrm{c}} \pm 0.18$ & $1.76^{\mathrm{b}} \pm 0.06$ & $69.02^{\mathrm{c}} \pm 0.41$ & $359.96^{\mathrm{a}} \pm 0.42$ \\
$\mathrm{M}_{3}$ & $9.72^{\mathrm{e}} \pm 0.02$ & $2.05^{\mathrm{c}} \pm 0.12$ & $2.88^{\mathrm{b}} \pm 0.03$ & $16.91^{\mathrm{a}} \pm 0.09$ & $2.10^{\mathrm{a}} \pm 0.08$ & $66.34^{\mathrm{e}} \pm 0.27$ & $358.90^{\mathrm{a}} \pm 0.99$ \\
$\mathrm{Lsd}_{0.05}$ & $0.05474^{*}$ & $0.1224^{*}$ & $0.1974^{*}$ & $0.2386^{*}$ & $0.1341^{*}$ & $0.3947^{*}$ & $1.361^{*}$ \\
$\mathrm{SE}^{*}$ & 0.01826 & 0.04082 & 0.06583 & 0.07958 & 0.04472 & 0.1317 & 0.4539 \\
\hline
\end{tabular}

Key: $\mathbf{S}=$ Bread made from decorticated sorghum, $\mathbf{S}_{\mathbf{1}}=$ Bread made from decorticated sorghum with $10 \%$ chickpea flour in the formulation., $\mathbf{S}_{2}=$ Bread made from decorticated sorghum with $20 \%$ chickpea flour in the formulation., $\mathbf{S}_{3}=$ Bread made from decorticated sorghum with $30 \%$ chickpea flour in the formulation., $\mathbf{M}=$ Bread made from decorticated maize., $\mathbf{M}_{1}=$ Bread made from decorticated maize with $10 \%$ chickpea flour in the formulation., $\mathbf{M}_{2}=$ Bread made from decorticated maize with $20 \%$ chickpea flour in the formulation., $\mathbf{M}_{3}=$ Bread made from decorticated maize with $30 \%$ chickpea flour in the formulation.

product attributes like texture and appearance. The crude protein content of experimental bread from decorticated sorghum and maize mixed different level of chickpea flour ranged from $10.08 \%$ to $16.91 \%$, for $\mathrm{S}$ and $\mathrm{M}_{3}$, respectively. From the current results protein content increased significantly $(P \leq 0.05)$ in sorghum and maize bread with increasing the level of chickpea flour in the formulation. The crude fiber content of breads made from decorticated sorghum and maize supplemented with different levels $(10 \%, 20 \%$, and $30 \%)$ of chickpea flour in the formulation ranged between 0.85 to $2.10 \%$. crude fiber increased significantly $(P \leq 0.05)$ with increasing the addition of chickpea flour in the ingredients breads of sorghum and breads of maize, respectively. No significant differences were noticed between breads from sorghum and breads of maize when the addition of chickpea flour reached to $30 \%$ in the bread formulation. The main role of fiber is to keep the digestive system healthy. Fiber has also been shown to benefit diabetes (Montonen, et al., 2003) [15], blood cholesterol levels (Anderson, et al., 2004) [16], reduces constipation, coronary, heart disease (Liu, et al., 1999) [17], and obesity (Lairon, et al., 2005) [18]. Carbohydrates content of breads made from decorticated sorghum and maize supplemented with different levels $(10 \%, 20 \%$, and $30 \%)$ of chickpea flour in the formulation are viewed in Table 1. The results of carbohydrates ranged between $66.34 \%$ to $74.51 \%$, whereas, $\mathrm{S}$ and $\mathrm{M}$, gained the highest values and the lowest values noted in $\mathrm{M}_{3}$. The addition of chickpea flour in the formulation of breads resulted a significant $(P \leq 0.05)$ decreased on carbohydrates with increasing the level chickpea flour. Energy values content of breads were in the range of 355.26 to $359.96 \mathrm{kcal} / 100 \mathrm{gm}$. Table 1 showed no significant differences were observed between energy values in all bread samples studied.

\subsection{Protein Digestibility of Tin Bread}

Table 2 showed incorporating of decorticated sorghum flour and also decorticated maize flour with chickpea flour by different levels $10 \%, 20 \%$, and $30 \%$ substantially increased significantly $(P \leq 0.05)$ in vitro protein digestibility of bread compared with $100 \%$ sorghum bread and also $100 \%$ maize bread. Replacement of sorghum bread flour by $10 \%, 20 \%$, and $30 \%$ of chickpea flour in the bread formulation appeared a significant increase in vitro protein digestibility from $43.35 \%$ to $45.51 \%, 46.62 \%$, and $48.22 \%$, respectively. These increments in digestibility of protein could be attributed to dilution of less digestible sorghum kafirins with more soluble chickpea globulins (MacLean, et al., 1981) [19]. Reported 46\% and 81\% apparent digestibility for sorghum and wheat, respectively in young children. Improved protein digestibility suggests potentially improved protein absorption and retention in humans. The results showed that maize bread protein digestibility varied from $50.78 \%$ to $58.54 \%$. It's clear that in vitro protein digestibility of maize bread was increased with increasing the level of chickpea flour in maize bread. 
Table 2. Protein and starch digestibility of tin breads.

\begin{tabular}{ccc}
\hline Samples & Protein digestibility (\%) & Starch digestibility (\%) \\
\hline $\mathrm{S}$ & $43.35^{\mathrm{h}} \pm 0.05$ & $62.55^{\mathrm{f}} \pm 0.10$ \\
$\mathrm{~S}_{1}$ & $45.51^{\mathrm{g}} \pm 0.02$ & $63.35^{\mathrm{e}} \pm 0.09$ \\
$\mathrm{~S}_{2}$ & $46.62^{\mathrm{f}} \pm 0.09$ & $65.24^{\mathrm{d}} \pm 0.08$ \\
$\mathrm{~S}_{3}$ & $48.22^{\mathrm{e}} \pm 0.05$ & $66.11^{\mathrm{c}} \pm 0.05$ \\
$\mathrm{M}$ & $50.78^{\mathrm{c}} \pm 0.05$ & $66.77^{\mathrm{b}} \pm 0.15$ \\
$\mathrm{M}_{1}$ & $53.65^{\mathrm{c}} \pm 0.03$ & $67.54^{\mathrm{a}} \pm 0.33$ \\
$\mathrm{M}_{2}$ & $55.80^{\mathrm{b}} \pm 0.04$ & $67.43^{\mathrm{a}} \pm 0.05$ \\
$\mathrm{M}_{3}$ & $58.54^{\mathrm{a}} \pm 0.06$ & $67.41^{\mathrm{a}} \pm 0.11$ \\
Lsd $_{0.05}$ & $0.09481^{*}$ & $0.2567^{*}$ \\
$\mathrm{SE}$ & 0.03162 & 0.08563
\end{tabular}

Values are mean SD. Mean(s) having different superscript(s) in a column are significantly different $(P \leq 0.05)$ according to DMRT.

\subsection{Starch Digestibility of Tin Bread}

Table 2 shows that starch digestibility of tin bread produced from decorticated sorghum and maize compositing with different levels $(0 \%, 10 \%, 20 \%$, and $30 \%)$ of chickpea flour in the bread formulations. Starch digestibility of sorghum bread ranged between $62.55 \%$ to $66.11 \%$. The results appeared that the significant increment in starch digestibility resulted due to the inclusion of chickpea flour in sorghum breads formulations.

The continuous increment in starch digestibility was resulted from the increment of chickpea levels. Several intrinsic factors in various sorghums could influence digestion rates of starch and protein including phenolic compounds (other than condensed tannin), phytate and kafirin, the dominant protein fraction in sorghum (Selle, et al., 2010) [20].

The value of starch digestibility of decorticated maize breads with chickpea flour in the formulation ranged from $66.77 \%$ to $67.43 \%$. From the current results of starch digestibility of maize breads increased significantly $(P \leq 0.05)$ with addition of chickpea flour to decorticated maize breads. No significant differences were noticed between $\mathrm{M}_{1}, \mathrm{M}_{2}$ and $\mathrm{M}_{3}$. Bread is an open structure with many air holes. According to Van der Merwe, et al., (2001) [21], the porous structure of bread increases the contact surface area of the sample with the enzymes during digestion. A great accessibility of starch in the bread contributes to the high rate of starch digestibility during the digestion period. During digestion, carbohydrates that break down quickly have high glycemic indexes (giving fast and high glucose responses). On the other hand, carbohydrates that break down slowly have low glycemic indexes (releasing glucose gradually into the blood stream). Lowering postprandial blood glucose (by consuming low GI foods) has positive health outcomes for both healthy subjects and patients with insulin resistance. These effects are summarized by Lang, (2004) [22].

\subsection{Loaf Specific Volume of Tin Bread}

Loaf specific volume of tin breads prepared from decorticated sorghum and maize incorporated with different levels of chickpea flour $(0 \%, 10 \%, 20 \%$, and $30 \%)$ in the formulations are presented in Table 3.

Table 3 showed loaf volume of breads were 338.33, 336.67, 340.0 and $340.0 \mathrm{~cm}^{3}$ for sorghum bread and breads from sorghum included with 10, 20, and 30\% chickpea flour, respectively. The results show there were no significant differences $(P \leq 0.05)$ in loaf volume due to the presence or absence of chickpea flour among decorticated sorghum bread and breads from sorghum with chickpea flour with different levels in the formulations. On the other hand, loaf volume of maize bread and breads form maize included with 10, 20, and 30\% chickpea flour in the formulations were 291.67, 273.33, 305.0 and $318.33 \mathrm{~cm}^{3}$, respectively. The results showed loaf weight increased significantly $(P \leq 0.05)$ in all samples studied compared with sorghum and maize without chickpea flour. Loaf specific volumes of breads produced were 2.79, $2.61,2.55$ and $2.54 \mathrm{~cm}^{3} / \mathrm{gm}$ for sorghum bread and its treatments breads included chickpea, respectively. Likewise, 2.43, 2.11, 2.30 and $2.46 \mathrm{~cm}^{3} / \mathrm{gm}$. For 
Table 3. Loaf specific volume of (gluten-fee) tin bread.

\begin{tabular}{cccc}
\hline Sample & Loaf volume $\mathrm{cm}^{3}$ & Loaf weight gm & Loaf specific volume $\mathrm{cm}^{3} / \mathrm{gm}^{\circ}$ \\
\hline $\mathrm{S}$ & $338.33^{\mathrm{a}}( \pm 7.64)$ & $121.07^{\mathrm{b}}( \pm 0.76)$ & $2.79^{\mathrm{a}}( \pm 0.06)$ \\
$\mathrm{S}_{1}$ & $336.67^{\mathrm{ab}}( \pm 5.77)$ & $128.70^{\mathrm{a}}( \pm 1.18)$ & $2.61^{\mathrm{b}}( \pm 0.05)$ \\
$\mathrm{S}_{2}$ & $340.00^{\mathrm{a}}( \pm 10.00)$ & $132.93^{\mathrm{a}}( \pm 2.41)$ & $2.55^{\mathrm{bc}}( \pm 0.06)$ \\
$\mathrm{S}_{3}$ & $340.00^{\mathrm{a}}( \pm 0.00)$ & $133.83^{\mathrm{a}}( \pm 1.10)$ & $2.54^{\mathrm{bc}}( \pm 0.02)$ \\
$\mathrm{M}$ & $291.67^{\mathrm{de}}( \pm 14.43)$ & $119.90^{\mathrm{b}}( \pm 1.21)$ & $2.43^{\mathrm{c}}( \pm 0.11)$ \\
$\mathrm{M}_{1}$ & $273.33^{\mathrm{e}}( \pm 7.64)$ & $129.63^{\mathrm{a}}( \pm 2.61)$ & $2.11^{\mathrm{e}}( \pm 0.03)$ \\
$\mathrm{M}_{2}$ & $305.00^{\mathrm{cd}}( \pm 17.32)$ & $132.43^{\mathrm{a}}( \pm 3.93)$ & $2.30^{\mathrm{d}}( \pm 0.11)$ \\
$\mathrm{M}_{3}$ & $318.33^{\mathrm{bc}}( \pm 12.58)$ & $129.50^{\mathrm{a}}( \pm 5.41)$ & $2.46^{\mathrm{c}}( \pm 0.08)$ \\
$\mathrm{Lsd}_{0.05}$ & $18.53^{* *}$ & $4.816^{* *}$ & $0.1224^{*}$ \\
$\mathrm{SE}^{*}$ & 6.18 & 1.606 & 0.04082 \\
\hline
\end{tabular}

Values are mean \pm SD. Mean value(s) sharing same superscript(s) in a column are not significantly different $(P>0.05)$.

maize bread and its treatments breads with chickpea, respectively. Loaf specific volume of breads produced decreased significantly $(P \leq 0.05)$ compared with sorghum bread. Nunes, et al., (2009) [23] showed that it did not have such a positive impact on loaf specific volume for gluten free breads. According to Sciarini, et al., (2010) [24], gluten-free breads have a smaller specific volume, with an average of $2.32 \mathrm{~cm}^{3} / \mathrm{gm}$ than wheat bread (average specific volume of $4.41 \mathrm{~cm}^{3} / \mathrm{gm}$ ). Generally, our sorghum and maize breads and their treatments breads with chickpea flour had a higher loaf specific volume compared to the average gluten free breads reported by Sciarini, et al., (2010) [24].

\subsection{Sensory Evaluation of Tin Bread}

The organoleptic properties of gluten free bread (Tin Bread) produced from decorticated sorghum and maize incorporated with 0\%, 10\%, 20\% and 30\% level chickpea flour was presented in Table 4.

One of the limiting factors for the consumer acceptability is the organoleptic properties therefore; color, odor, taste, crumb texture, crumb grain and general acceptability were performed. Table 4 showed that the results of color scores of bread produced from decorticated maize incorporated with different levels of chickpea flour ranged between 6.14 to 6.79 score, and it had been accepted. No significant differences $(P \leq 0.05)$ were obtained, but significant differences $(P \leq 0.05)$ were noted comparing with decorticated maize bread without chickpea flour inclusion, decorticated sorghum bread and sorghum breads with different levels of chickpea flour in the formulations. Likewise, the entire samples had been accepted. Odor scores ranged between 3.64 to 5.71score, no significant differences $(P \leq 0.05)$ were noticed compared with sorghum and maize breads without chickpea flour in the formulations. The taste values of bread products had been accepted comparing with sorghum and maize breads without chickpea flour, no significant differences were observed. Crumb texture and crumb grain of breads produced had been accepted. The scores of crumb texture and crumb grain of breads produced showed no significant differences $(P \leq 0.05)$ were observed compared with sorghum and maize breads scores. General acceptability of breads produced showed no significant differences were noticed, that means all samples treated studied were accepted. The mean comparison of scores of different attributes like texture, flavor, taste, appearance, mouth feels and over acceptability were recorded and found to be non significant differences with treatment group (Dhore, 2011) [25].

\section{Conclusion}

Inclusion of chickpea flour to gluten free breads (tin breads) improved the proximate composition, protein and 
Table 4. Sensory evaluation (gluten-free) tin bread.

\begin{tabular}{|c|c|c|c|c|c|c|}
\hline Sample & Colour & Odour & Taste & Crumb texture & Crumb grains & General acceptability \\
\hline $\mathrm{S}$ & $3.21^{b} \pm 2.42$ & $4.57^{\mathrm{ab}} \pm 3.11$ & $4.29^{\mathrm{ab}} \pm 2.95$ & $3.86^{\mathrm{a}} \pm 2.63$ & $4.36^{\mathrm{c}} \pm 2.73$ & $4.50^{\mathrm{ab}} \pm 3.25$ \\
\hline $\mathrm{S}_{1}$ & $3.07^{\mathrm{b}} \pm 1.98$ & $3.64^{b} \pm 2.44$ & $3.29^{b} \pm 1.64$ & $4.21^{\mathrm{a}} \pm 2.67$ & $4.36^{\mathrm{bc}} \pm 2.31$ & $3.36^{\mathrm{b}} \pm 2.37$ \\
\hline $\mathrm{S}_{2}$ & $3.71^{b} \pm 2.13$ & $3.71^{\mathrm{ab}} \pm 2.09$ & $3.71^{\mathrm{ab}} \pm 1.86$ & $4.07^{\mathrm{a}} \pm 1.90$ & $4.50^{\mathrm{abc}} \pm 1.91$ & $4.00^{\mathrm{ab}} \pm 2.29$ \\
\hline $\mathrm{S}_{3}$ & $4.14^{\mathrm{b}} \pm 1.56$ & $4.00^{\mathrm{ab}} \pm 1.80$ & $4.36^{\mathrm{ab}} \pm 1.82$ & $4.14^{\mathrm{a}} \pm 1.61$ & $4.64^{\mathrm{abc}} \pm 1.65$ & $4.29^{\mathrm{ab}} \pm 1.90$ \\
\hline M & $6.79^{b} \pm 2.01$ & $5.43^{\mathrm{ab}} \pm 2.59$ & $5.50^{\mathrm{a}} \pm 2.35$ & $5.43^{\mathrm{a}} \pm 2.10$ & $5.36^{\mathrm{ab}} \pm 2.02$ & $6.07^{\mathrm{a}} \pm 2.27$ \\
\hline $\mathbf{M}_{1}$ & $6.21^{\mathrm{a}} \pm 1.97$ & $5.21^{\mathrm{ab}} \pm 2.15$ & $4.93^{\mathrm{ab}} \pm 2.09$ & $5.00^{\mathrm{a}} \pm 2.18$ & $5.71^{\mathrm{abc}} \pm 2.09$ & $5.36^{\mathrm{ab}} \pm 2.47$ \\
\hline $\mathrm{M}_{2}$ & $6.50^{\mathrm{a}} \pm 1.61$ & $5.71^{\mathrm{a}} \pm 2.16$ & $5.07^{\mathrm{ab}} \pm 2.16$ & $5.00^{\mathrm{a}} \pm 2.39$ & $5.64^{\mathrm{abc}} \pm 2.10$ & $5.64^{\mathrm{a}} \pm 2.41$ \\
\hline $\mathrm{M}_{3}$ & $6.14^{\mathrm{a}} \pm 1.83$ & $5.14^{\mathrm{ab}} \pm 2.07$ & $4.71^{\mathrm{ab}} \pm 2.16$ & $5.36^{\mathrm{a}} \pm 2.50$ & $5.43^{\mathrm{a}} \pm 2.24$ & $4.93^{\mathrm{ab}} \pm 2.37$ \\
\hline $\operatorname{Lsd}_{0.05}$ & $1.466^{*}$ & $1.748^{*}$ & $1.62^{*}$ & $1.704^{\mathrm{n} . \mathrm{s}}$ & $1.613^{\mathrm{n} . \mathrm{s}}$ & $1.83^{*}$ \\
\hline $\mathrm{SE} \pm$ & 0.5227 & 0.6234 & 0.5777 & 0.5442 & 0.5753 & 0.6525 \\
\hline
\end{tabular}

Values are mean \pm SD. Mean value(s) sharing same superscript(s) in a column are not significantly different $(P>0.05)$.

starch digestibility. The breads produced could solve the problems of lack of gluten free breads for consumers and especial groups (celiac disease patients) with good quality and acceptable. Gluten-free products could be substituted for those with special dietary needs or metabolism.

\section{References}

[1] Schober, T.J., Messerschmidt, M., Bean, S.R., Park, S.H. and Arendt, E.K. (2005) Gluten-Free Bread from Sorghum: Quality Differences among Hybrids. Cereal Chemistry, 82, 394-404. http://dx.doi.org/10.1094/CC-82-0394

[2] Frederick, E.J. (2009) Effect of Sorghum Flour Composition and Particle Size on Quality of Gluten-Free Bread. Masters' Thesis, Kansas State University Library, 113 p.

[3] Marston, K.G. (2009) Effect of Sorghum Flour Treated with Ozone and Heat on the Quality of Gluten-Free Bread and Cake. Masters’ Thesis, Kansas State University Library, 98 p.

[4] Schober, T.J. (2009) Manufacture of Gluten-Free Specially Breads and Confectionery Products. In: Gallagher, E., Ed., Gluten-Free Food Science and Technology, Wiley-Blackwell, UK, 130-180.

[5] Fasano, A. and Catassi, C. (2001) Current Approaches to Diagnosis and Treatment of Celiac Disease: An Evolving Spectrum. Gastroenterology, 120, 636-651. http://dx.doi.org/10.1053/gast.2001.22123

[6] Kagnoff, M.F., Austin, R.K., Johnson, H.C., Bernardin, J.E., Dietler, M.D. and Kasarda, D.D. (1982) Celiac Sprue: Correlation with Murine T Cell Responses to Wheat Gliadin Components. Journal of Immunology, 129, $2693-2697$.

[7] Van de Wal, Y., Kooy, Y.M.C., Van Veelen, P., Vader, W., August, S.A., Drijfhout, J.W., Peña, S.A. and Koning, F. (1999) Glutenin Is Involved in the Gluten-Driven Mucosal T Cell Response. European Journal of Immunology, 29, 3133-3139. http://dx.doi.org/10.1002/(SICI)1521-4141(199910)29:10<3133::AID-IMMU3133>3.0.CO;2-G

[8] AOAC (2000) Official Methods of Analysis of the Association of Official Analytical Chemists. 17th Edition, Washington DC.

[9] A. A. C. C. (2000) Approved Methods of American Association of Cereal Chem. 10th Edition, St. Paul.

[10] West, C.E., Repping, F. and Temalilwa, C.R. (1988) Handbook on the Composition of Food Commonly Eaten in East Africa. Published by Wangnening, The Netherlands.

[11] Atwater, W.O. and Benedict, F.G. (1902) Experiments on the Metabolism of Matter and Energy in the Human Body, 1898-1900. US Office of Experiment Stations Bulletin No. 109, Government Printing Office, Washington DC.

[12] Mouliswar, P., Kurien, S., Daniel, V.A., Malleshi, N.G. and Venkatarao, S. (1993). In Vitro Digestibility of Protein and Starch as Energy Food and Its Bulk Reduction. Journal of Food Science and Technology, 30, 36-39.

[13] A. A. C. C. (1969) American Association of Cereal Chemists. A. A. C. C. Approved Methods (Formerly Cereal Laboratory Methods). 7th Edition, Method No. 76-10. St. Paul, Minn.

[14] Badi, S.M., Elfaki, H.A. and Perten, H. (1978) Evaluation of Sudanese Wheat Varieties. Sudan J. of Food Sci. and Techno., 10, 5. 
[15] Montonen, J., Knekt, P., Jarvinen, R., Aromaa, A. and Reunanen, A. (2003) Whole Grain and Fiber Intake and the Incidence of Type 2 Diabetes. American Journal of Clinical Nutrition, 77, 622-629.

[16] Anderson, J.W., Randles, K.M., Kendall, C.W.C. and Jenkins, D.J.A. (2004) Carbohydrate and Fiber Recommendations for Individuals with Diabetes: A Quantitative Assessment and Meta-Analysis of the Evidence. Journal of the American College of Nutrition, 23, 5-17. http://dx.doi.org/10.1080/07315724.2004.10719338

[17] Liu, S., Stampfer, M.J. and Hu, F.B. (1999) Whole-Grain Consumption and Risk of Coronary Heart Disease: Results from the Nurses' Health Study. American Journal of Clinical Nutrition, 70, 412-419.

[18] Lairon, D., Arnault, N. and Bertrais, S. (2005) Dietary Fiber Intake and Risk Factors for Cardiovascular Disease in French Adults. American Journal of Clinical Nutrition, 82, 1185-1194.

[19] MacLean, W.C., Lopez de Romaña, G., Placko, R.P. and Graham, G.G. (1981) Protein Quality and Digestibility of Sorghum in Preschool Children: Balance Studies and Plasma Amino Acid. Journal of Nutrition, 111, 1928-1936.

[20] Selle, P.H., Cadogan, D.J., Li, X. and Bryden, W.L. (2010) Implications of Sorghum in Broiler Chicken Nutrition. Animal Feed Science and Technology, 156, 57-74. http://dx.doi.org/10.1016/j.anifeedsci.2010.01.004

[21] Van der Merwe, B., Erasmus, C. and Taylor, J.R.N. (2001) African Maize Porridge: A Food with Slow in Vitro Starch Digestibility. Food Chemistry, 72, 347-353. http://dx.doi.org/10.1016/S0308-8146(00)00235-1

[22] Lang, V. (2004) Development of a Range of Industrialized Cereal-Based Food Stuffs, High in Slowly Digestible Starch. In: Elisasson, A.-C., Ed., Starch in Food, CRC Press LLC, Boca Raton, 477-504.

[23] Nunes, M.H.B., Moore, M.M., Ryan, L.A.M. and Arendt, A.K. (2009) Impact of Emulsifiers on the Quality and Rheological Properties of Gluten-Free Breads and Batters. European Food Research and Technology, 228, 633-642. http://dx.doi.org/10.1007/s00217-008-0972-1

[24] Sciarini, L.S., Ribotta, P.D., Leon, A.E. and Perez, G.T. (2010) Influence of Gluten-Free Flours and Their Mixtures on Batter Properties and Bread Quality. Food and Bioprocess Technology, 3, 577-585. http://dx.doi.org/10.1007/s11947-008-0098-2

[25] Dhore, K.R. (2011) Sensory Evaluation of Sorghum Chakali Enriched with Different Levels of Soya Bean Flours. International Referred Research Journal, 3, 50-51. 